\title{
Hospitalization of Deliveries: the Change of Place of Birth in Denmark and Sweden from the Late Nineteenth Century to 1970
}

\author{
SIGNILD VALLGÅRDA*
}

\section{Introduction}

Sweden was one of the first countries in western Europe where deliveries in hospitals and clinics replaced home deliveries. Denmark, her close neighbour, was one of the last. This paper attempts to identify various factors involved in this change and especially to find out why it occurred so much earlier in Sweden.

At the end of the nineteenth century practically all Swedish and Danish women gave birth at home. By 1945, however, this was no longer the case. In Sweden only 27 per cent of women still gave birth at home compared with 63 per cent of Danish women. In Sweden the great change from home to hospital births took place in the 1920s and 1930s, in Denmark in the 1950s and 1960s (see Figure 1). In most other European countries the change occurred between these years: in England and Wales 25 per cent of births took place in hospital in $1938^{1}$ and 66 per cent in $1954,{ }^{2}$ in Norway 74 per cent of children were born in hospital in $1951,{ }^{3}$ and in Finland 58 per cent in $1950 ;{ }^{4}$ only in the Netherlands were home births still common at 35 per cent in $1978 . .^{5}$ In the eighteenth century in both Denmark and Sweden one maternity hospital was established as a political means to promote population growth. These hospitals were founded to provide unmarried mothers with a place of delivery, to prevent infanticide, and also to facilitate the education of midwives and doctors in midwifery, with the aim of reducing infant mortality. ${ }^{6}$ During the nineteenth century six more maternity hospitals or departments in existing hospitals were

*Dr Signild Vallgårda, Department of Social Medicine, University of Copenhagen, Blegdamsvej 3, 2200 Copenhagen N, Denmark.

Det Kommunale Momsfond has supported my study financially. Several people have made helpful criticisms of, and comments on, this paper, not least the referees of Medical History.

\footnotetext{
${ }^{1}$ Irvine Loudon, Death in childbirth: an international study of maternal care and maternal mortality 1800-1950, Oxford, Clarendon Press, 1992, p. 231.

2 Alisoh MacFarlane, Miranda Mugford, Birth Counts. Statistics of pregnancy and childbirth, London, HMSO, 1984, p. 237.

3 Ida Blom, "Den haande Dyst" Fødsler og fodselshjalp gjennom 150 år, Oslo, Cappelen, 1998, p. 224.
}

\footnotetext{
${ }^{4}$ Elina Hemminki, 'Obstetric practices in Finland 1950-1980', Medical Care, 1983, 21: 1131-43, on p. 1132.

5 P E Treffers, $R$ Laan, 'Regional perinatal mortality rates and regional hospitalization at delivery in the Netherlands', Br. J. Obstet. Gynaec., 1986, 93: 690-3.

${ }^{6}$ Confirmation paa Dronning Juliane Maries Gavebrev af 29. Jan. 1785, hvorved en Gaard og 25 vestindiske Aktier skienkes til Fødselsstiftelsen; Gordon Norrie, 'Jordemodervæsenets Udvikling i Danmark', Tidsskrift for danske Jordem $\phi$ dre, 1895 , 5: 143; Birger Lundqvist, 'Det svenska barnmorskeväsendets historia', in B Lundqvist (ed.), Svenska barnmorskor, Stockholm, Svenska yrkesförlaget, 1940, p. 50ff.
} 


\section{Signild Vallgårda}

Figure 1: Home confinements as a proportion of all births in Denmark and Sweden.

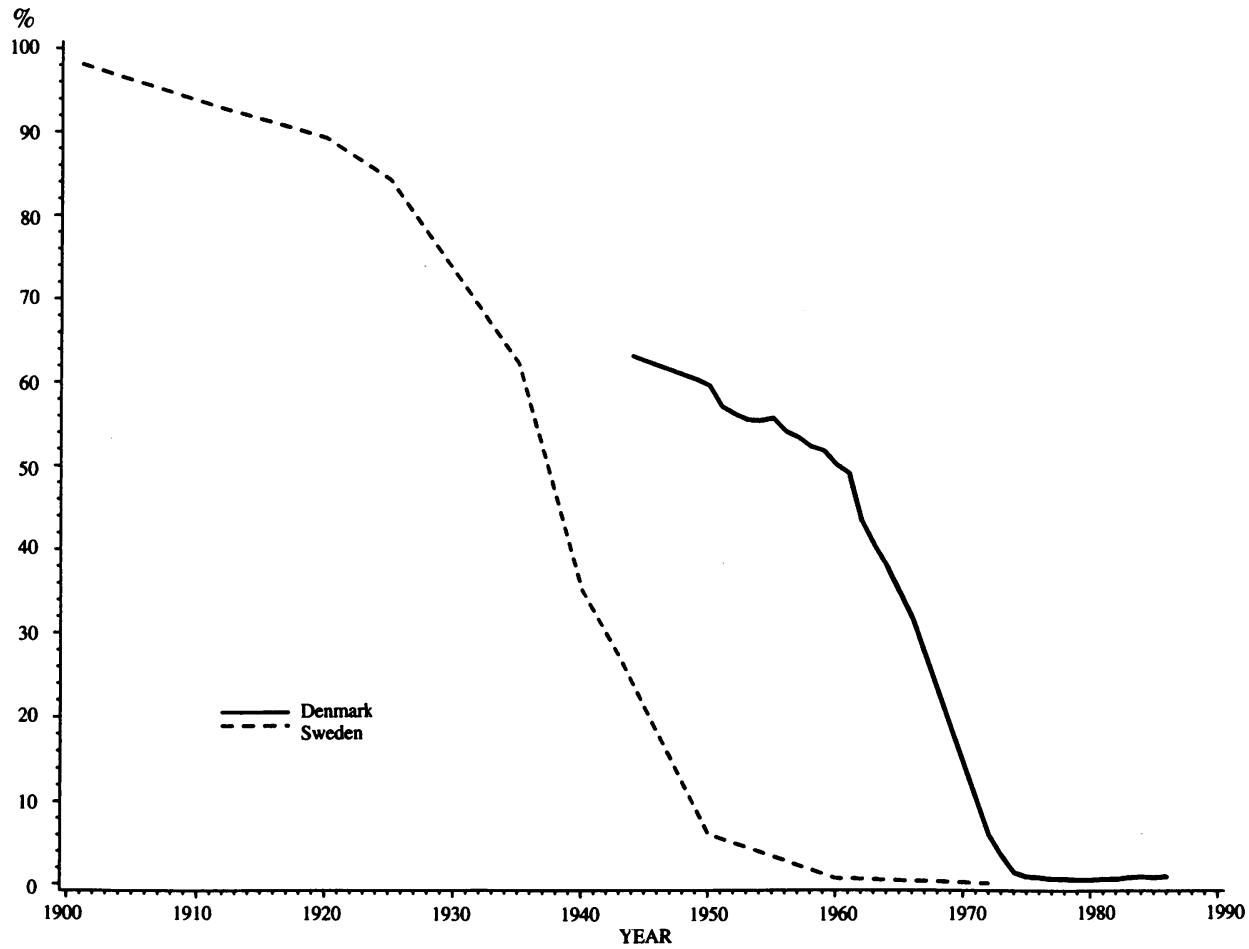

Sources: Medicinalberetning I, Copenhagen, Sudhedsstyrelsen, annual publication;

Förlossningsvårdens organisation, Socialstyrelsen redovisar no. 35, Stockholm, Socialstyrelsen, 1973.

created in Sweden, with a total of 216 beds and 4 to 5 per cent of the deliveries in $1900 .^{7}$ In Denmark a second maternity hospital was established only as late as 1910 . From the beginning of the twentieth century maternity hospitals and clinics were founded in both countries, but in greater numbers in Sweden. ${ }^{8}$ During this century, women have given birth in a variety of places: their own homes, hospitals, or maternity homes. The latter were either private, mainly for the better off, or were owned by municipalities, or charity organizations such as the Red Cross, for women of the poorer classes. The reasons for creating and using these establishments varied, depending on their type and the social class of the women utilizing them. Both types paved the way for hospital deliveries throughout the population. The use of these reached a peak in 1934 when 20 per cent of Swedish deliveries occurred in such smaller maternity institutions. By 1943 the figure had declined to 11 per cent. For Denmark there are no statistics available until 1950, when 14

\footnotetext{
${ }^{7}$ Betänkande angående moderskapsskydd, Statens Offentliga Utredningar (hereafter SOU) 1929:28, Stockholm, Socialdepartementet, 1929.

${ }^{8}$ Betänkande angående förlossningsvården och barnmorskeväsendet samt förebyggande mödra- och barnavård avgivet av befolkningskommissionen, SOU 1936:12, Stockholm, Socialdepartementet,
}

1936, p. 105; Betänkande om förlossningsvården avgivet af 1941 ars befolkningskommission, SOU 1945:50, Stockholm, Socialdepartementet, p. 167; Betankning II afgivet af det af Indenrigsministeriet nedsatte udvalg vedrørende fødselshjalp $m v$,

Betænkning 160, Copenhagen, Indenrigsministeriet, 1956. 


\section{The Change of Place of Birth in Denmark and Sweden}

per cent of children were born in maternity homes; in 1970 the number was 16 per cent.

It is curious that the two countries differ so much as regards place of birth since, in general, they have very similar patterns of political and social development. They both have long traditions of democracy and public responsibility for social welfare, health and education. From the end of the nineteenth century onwards the labour unions and the Social Democratic parties have had an increasing influence, although larger in Sweden than in Denmark. The state and municipalities provided schools, relief for the poor, and health care to a varying extent, at least from the eighteenth century. Charity played a minor role in both countries. There are, however, differences. The degree of urbanization was higher in Denmark at the turn of the century (see Figure 2), but in Sweden urbanization and industrialization progressed very rapidly during the first decades of the nineteenth century. The change in Sweden was more radical in another sense as well. In Denmark the dominant form of industrialization mainly involved the establishment of small-scale industries. There was much similarity between farms and small industries in the way work was organized and in relations between workers and employers, but in Sweden heavy industry and large plants were more common. These created new communities and new types of social relations. Thus the social change in Sweden from agriculture to industry, and from rural to urban life, was faster and more fundamental than in Denmark. In spite

Figure 2: Proportion of the population living from farming.

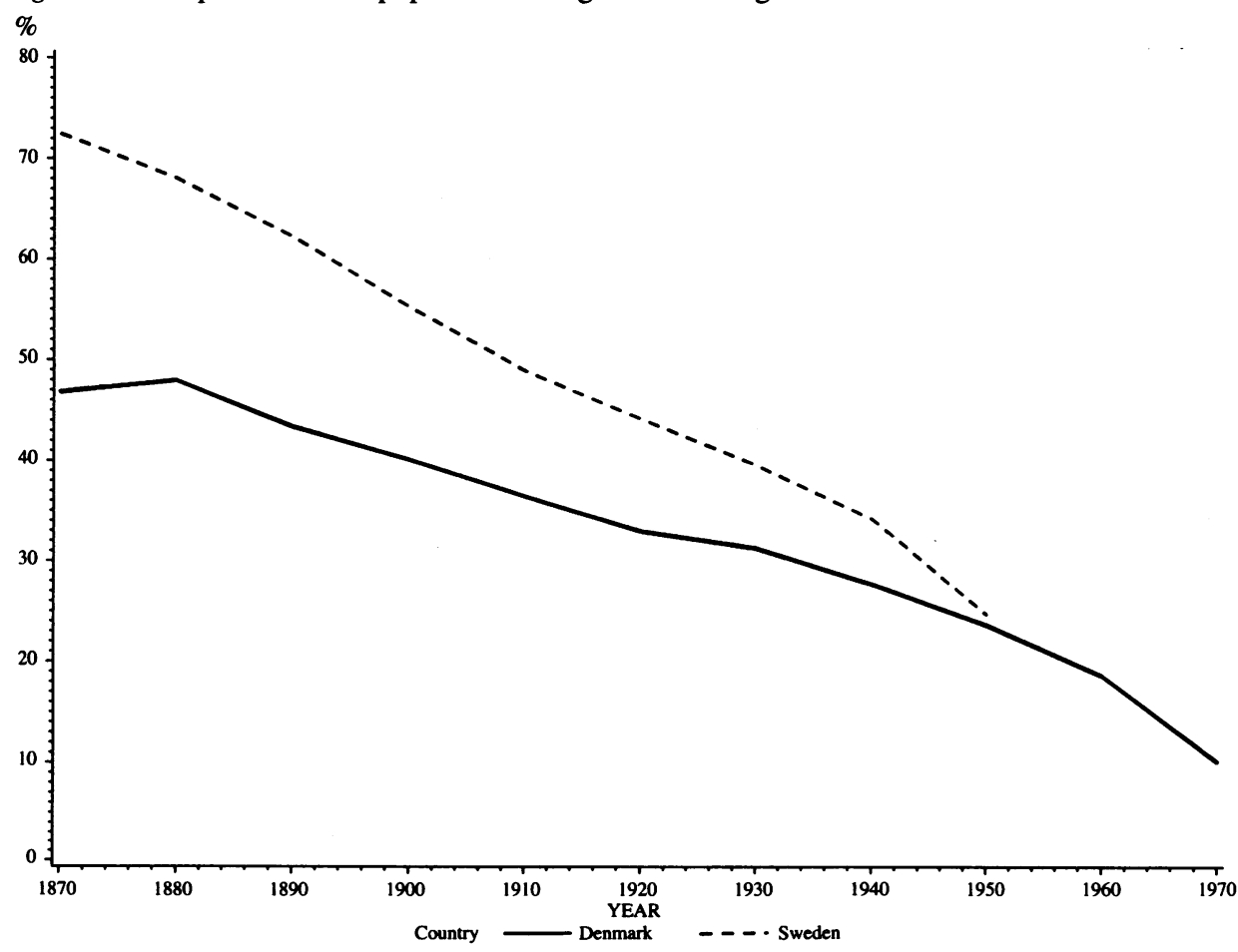

Sources: Historisk statistik för Sverige, vol. 1, Stockholm, Statistiska Centralbyrån, 1969; Hans Chr. Johansen, Danmarks historie, vol. 9, Danish historical statistics 1814-1980, Copenhagen, Gyldendal, 1985. 


\section{Signild Vallgårda}

of these differences, hospitals were built and expanded almost simultaneously, see below, but not maternity hospitals, as shown above.

\section{Methods and Materials}

When a specific change in health care is studied, many factors must be considered. These include changes in population and in society at large such as urbanization and industrialization, which are the results of individuals' actions, and at the same time set the conditions for social behaviour. The ideas and actions of different groups involved in the health care process also need to be taken into account. In this study the relevant groups are: pregnant women, since their beliefs and wishes are decisive for the places where they give birth, at least when they have a choice; the midwives, who play a role, albeit not a very influential one, in advising pregnant women whether hospital deliveries should be favoured or not, and also through writing in their own journal and sometimes in the newspapers; and the doctors, who as "experts" tend to influence politicians, also write in journals and newspapers and, not least, are used as advisors and as members of different committees set up to deal with maternity care. The political administrative tradition in Sweden involves much more committee work, and many more reports and white papers are written and published than in Denmark. That type of source material is thus much more abundant in Sweden. Through their services, doctors also influence women. In addition, the ideas of politicians and bureaucrats must be studied. These last two groups, in particular, influence the societal framework, including the health care system, through finance and legal restrictions. They may well have different ideas and motives for trying to achieve a common goal, such as hospitalization of deliveries, or the opposite. Before analysing these ideas, I will look at the organization of health care in the two countries.

\section{Organization and Resources of the Health Care Sector}

To what extent can organizational differences in the health care sectors in the two countries explain the differences in the choice of place of delivery? Hospitals have been the responsibility of the counties in Denmark since the eighteenth century and in Sweden since 1860. Very few private hospitals existed in either country. The degree of centralization has been said to have influenced the degree of hospitalization of deliveries, since obstetricians exerted more influence over the state than over decentralized organizations. ${ }^{9}$ In this respect the two countries do not differ. The degree of centralization of health care decisions has not been a factor influencing the rate of hospitalization in the two countries.

Health insurance schemes existed in both countries, although coverage was more extensive in Denmark until the 1950s. ${ }^{10}$ In 190012.4 per cent of Danes were covered by health insurance schemes, as compared with 5.1 per cent of the Swedish population. Thirty years later the coverage was 46.5 per cent in Denmark and only 16.6 per cent in

\footnotetext{
${ }^{9}$ A Torres, M R Reich, 'The shift from home to institutional childbirth: a comparative study of the United Kingdom and the Netherlands', Int. J. Health Stud., 1989, 19: 405-15.
}

${ }^{10}$ Hirobumi Ito, Health insurance policy development in Denmark and Sweden 1860-1950, Copenhagen, Joint Center for Studies of Health Care Programs, 1978. 


\section{The Change of Place of Birth in Denmark and Sweden}

Sweden. Until the mid-1930s state subsidies constituted a much larger part of the Danish health insurance schemes' total income than the Swedish ones, and a high proportion of the Danish health insurance schemes' expenditure was used on medical treatment, while in Sweden, until the 1940s, almost all expenditure went on cash benefits. ${ }^{11}$ Thus the Danish health insurance scheme was more developed and had a greater impact on the expansion of the health care system than the Swedish during the first half of the twentieth century. The health insurance scheme could provide some help in connection with births, but in neither country was it compulsory. ${ }^{12}$ The extent of this support has not yet been investigated.

\section{Number and Availability of Midwives}

For most women, a prerequisite for delivery at home was that assistance would be available. The number of trained midwives increased in both countries during the nineteenth century, although faster in Denmark than in Sweden. In Denmark, a system of district midwives financed by the municipalities was introduced in 1810 , and it was well established by the turn of the century. The district midwife received a salary, heating and free housing for assisting the parturient women in her district, treating the poor free of charge and others according to their income. In 1791 the fees were fixed by the state: a farmer should pay 3 Marks, a peasant 2 Marks and a crofter 1 Mark. The first instructions for midwives were given in the church ordinance of 1539 , which laid down that they should assist poor and rich alike. A later ordinance of 1685 declared that they should receive what was fair for their services and help the poor for the sake of God. In 1714 it was stated that midwives were not allowed to leave a poor woman "for the sake of filthy profit". Solidarity with the poor thus had a long tradition in Denmark; until 1810, however, midwives were the only ones to pay a price for this solidarity. ${ }^{13}$ The district midwife system was abolished in 1973. In Sweden municipalities were requested by the state to engage midwives and by the end of the nineteenth century most of them had done so. Midwives were paid by the women they delivered according to regulated tariffs. In 1908 the municipalities were obliged to pay a minimum salary to midwives. During the 1920s the financial situation of midwives improved, and in 1937 an act was passed making all birth attendance free of charge, and all midwives were paid a fixed salary. In 1900 almost all Danish women giving birth were assisted by a trained midwife, while only 78 per cent of Swedish women were. ${ }^{14}$ Consequently, about 20 per cent of Swedish women had no trained assistance from either a midwife or a doctor, who hardly ever assisted at births without a midwife being present.

\footnotetext{
${ }^{11}$ Hirobumi Ito, 'Health insurance policy development in Denmark and Sweden 1860-1950', Social Sci. Med., 1979, 13C: 143-60.

12 Betänkande, op. cit., note 7 above; H C Hansen, Historien om sygekasserne, Ålborg, De samvirkende centralforeninger af sygekasser i Danmark, 1974, p. 86.

${ }^{13}$ Reglemente for Giordemodervasenets Indretning og Bestyrelse i begge Riger, Kiфbenhavn undtagen, 21 Nov. 1810; Rescript ang. at naar nogen herefter skulde vilde paatage sig Giordemødres forretning $i$ Kiøbenhavn og Christianshavn, 30 March 1714.
}

${ }^{14}$ Ulf Högberg, Svagårens barn, Stockholm, Liber förlag, 1983, p. 133; Anders Brändström, De kärlekslösa mödrarna, Umeå, Almqvist \& Wiksell, 1984, p. 59; Medicinalberetning for Kongeriget Danmark, Copenhagen, Sundhedsstyrelsen, annual publication, p. 170; Christina Romlid, 'The Swedish midwife system and the instrumental authorization of midwives', in Hilary Marland and Anne Marie Rafferty (eds), What is to be done with the midwife? Midwives and society 1850-1990s, London, Routledge, forthcoming. 


\section{Signild Vallgårda}

Since the end of the nineteenth century the number of midwives in Denmark has remained around 1,000 (see Figure 3), ${ }^{15}$ but the number of deliveries per midwife has differed widely (see Figure 4). In 1900 the annual number of deliveries per midwife in Denmark was 69, in 1925: 60 and in 1950: 100. In Sweden the numbers were in 1900: 49, in 1925: 36 and in 1950: 74. There are several reasons for these differences. The lower number of deliveries per midwife in Sweden could probably be partly explained by the fact that the country was so sparsely populated, and the very low number in 1925 was due to the sharp decline in fertility. The number of midwives started to fall towards the end of the 1920s. The higher number of deliveries per midwife in Denmark in 1950 could be ascribed to different tasks being undertaken by midwives in the two countries. In spite of the fact that a midwife at a hospital could manage more deliveries than a midwife assisting at home deliveries, Swedish hospital midwives were also supposed to care for lying-in women, while in Danish hospitals these women were cared for by nurses. At home births it was the task of the midwife to care for the lying-in woman and the child. However in Denmark from the Second World War, home nurses provided care for lying-in women, and they were paid for by either the women or the health insurance scheme. In 1972 (when statistics became available) lying-in women received an average of nine visits from a nurse. A system with maternity home care assistants like the one in the Netherlands never

Figure 3: Number of trained midwives in Denmark and Sweden.

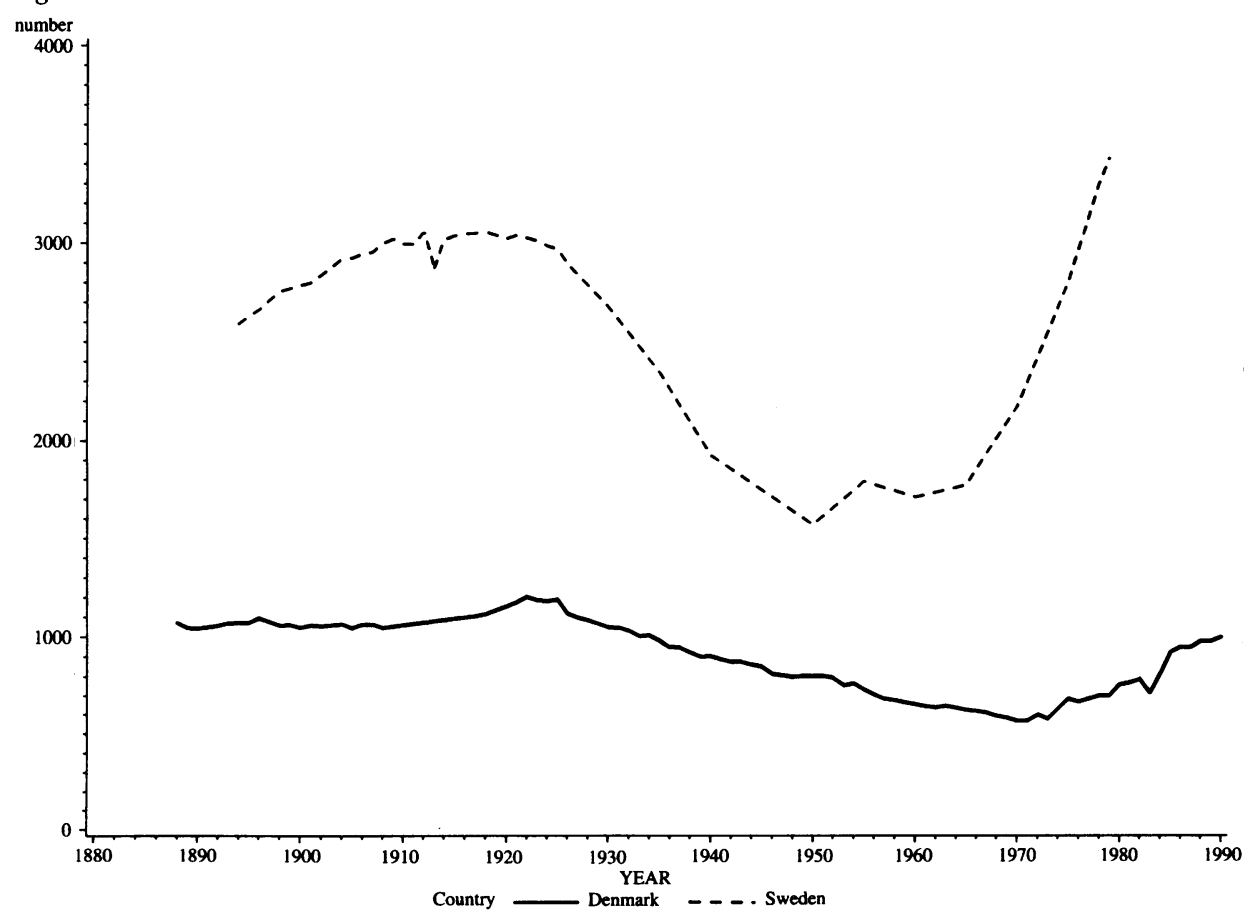

Sources: Medicinalberetning for Kongeriget Danmark, Copenhagen, Sundhedsstyrelsen, annual publication; Allmän hälso-och sjukvård. Medicinalstyrelsen, Stockholm, Socialstyrelsen, annual publication.

15 Medicinalberetning, op. cit., note 14 above. 
Figure 4: Number of deliveries per midwife in Denmark and Sweden.

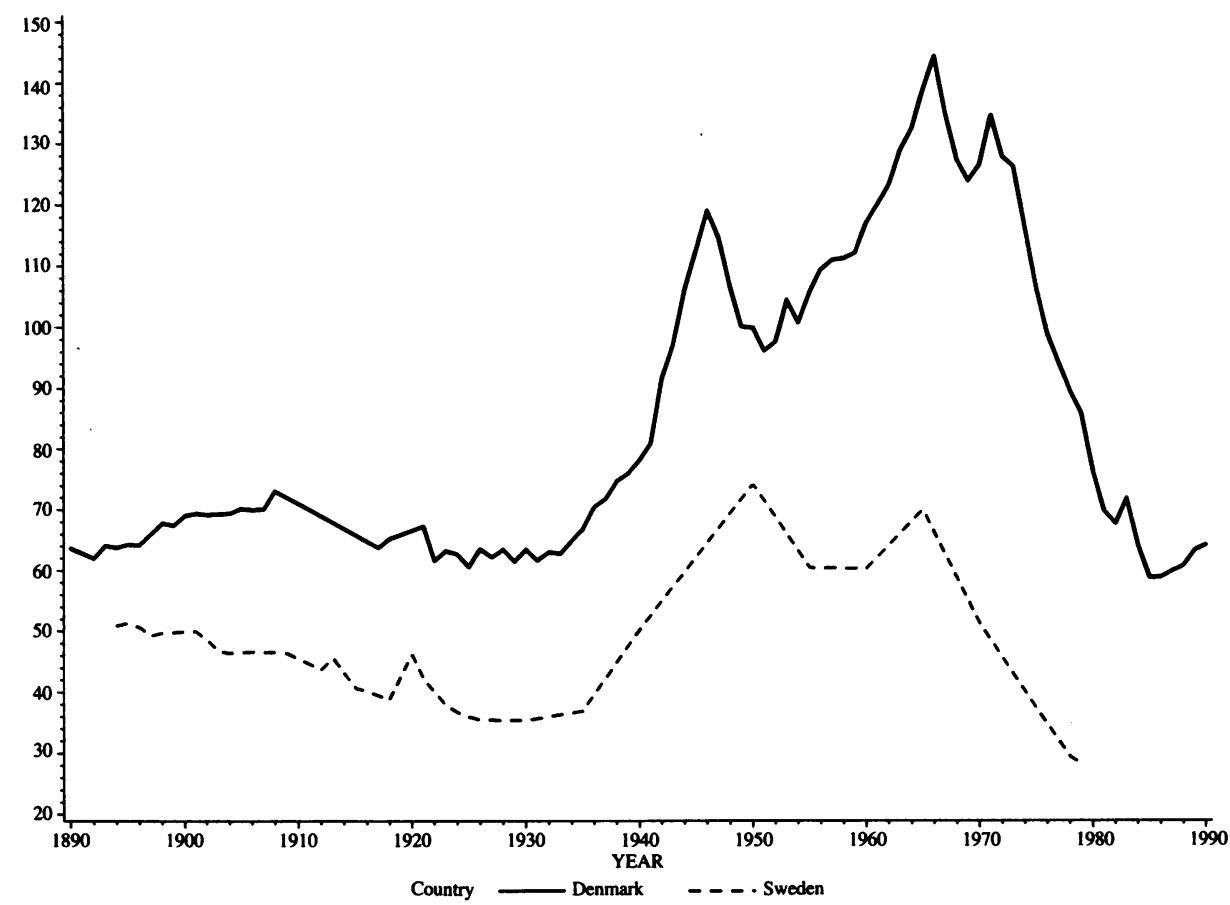

Sources: Medicinalberetning for Kongeriget Danmark, Copenhagen, Sundhedsstyrelsen, annual publication; Allmän hälso-och sjukvård. Medicinalstyrelsen, Stockholm, Socialstyrelsen, annual publication.

developed in either Denmark or Sweden. ${ }^{16}$ When it was a question of actual birth attendance midwives were present in both countries and they were responsible for all normal deliveries and gave assistance in the case of complicated ones, irrespective of whether the births took place in hospitals or in private homes. Doctors were summoned when complications arose, or threatened to arise, and when pain relief was required. Midwives in both countries participated in prenatal care.

In Sweden the number of midwives fell from about 3,000 in 1910 to about 1,500 in 1950 , but rose again in the 1960 s (see Figure 3). ${ }^{17}$ There are no reliable data on the problems of receiving midwife assistance at home, but the fear of not being able to receive it may have been an important factor which caused women go to hospital instead. In Sweden the number of midwife districts was reduced from 2,000 in 1924 to 1,100 in

\footnotetext{
${ }^{16} \mathrm{E} R$ van Teilingen, 'The profession of maternity home care assistant and its significance for the Dutch midwifery profession', Int. J. nurs. Stud., 1990, 27 : 355-66.

${ }^{17}$ Allmän hälso och sjukvård, Stockholm, Socialstyrelsen, annual publication. The ratio between the midwives and the total population in Sweden was approximately the same as in the
}

Netherlands. In 1895 the ratio was 1:5338 in Sweden, 1:5189 in Denmark, and 1:5793 in the Netherlands, see Hilary Marland, 'The guardians of normal birth: the debate on the standard and status of the midwife in the Netherlands around 1900', in Eva Abraham-van der Mark (ed.), Successful home birth and midwifery, Westport, Connecticut, Borgni \& Garvey, 1993, p. 30. 


\section{Signild Vallgårda}

$1939 ;^{18}$ thus the area each midwife covered was increased. This is the question of the chicken and the egg. Did the number of district midwives decline because women went to hospital to give birth, or did women go to hospital because of a shortage of midwives? The reasons probably differed from place to place. In any case the total number of deliveries fell before the number of midwives fell, which indicates that it was rather a lack of work for midwives than a scarcity of the midwives themselves which was the first step in the change. The sharp decline in the number of midwives in Sweden during the first decades of this century may have contributed in part to the increase in hospital deliveries. The fact that the provision of midwives was more stable in Denmark and that they were well established throughout the country at an earlier time may be one reason why Danish women continued to give birth at home.

The geographical differences between Denmark and Sweden are huge, Sweden having large sparsely populated areas. If this factor has influenced the place of birth, one might imagine that women in these areas went to hospital to be sure of receiving help. ${ }^{19}$ If so, one would expect home deliveries to be abandoned first in the very sparsely populated areas in the north of Sweden. The opposite, however, is the case. Home deliveries persisted longest in the northern parts of Sweden, while the cities saw an early move towards hospital deliveries (see Figure 5). Geographical differences between the two countries are thus not valid as an explanation of the differences in the health care system, at least not in this case. ${ }^{20}$ The availability of hospitals is of course a crucial factor, and distances to hospitals were greatest in the north. In Denmark, however, most women lived comparatively close to hospitals without using them in the case of childbirth, and the most urbanized area, Copenhagen and its suburbs, had a high percentage of hospital deliveries at an early point in time (see Figure 6) parallel to the Swedish development. Figures are not available from Denmark before 1949.

\section{Midwives' Training and Competence}

It has been suggested that the existence of well educated and independent professional midwives might favour the continuation of home deliveries. ${ }^{21}$ In the following section, I will examine the development of the training, competence and number of midwives in the two countries.

The teaching of midwifery, organized and financed by the central state, began in the late eighteenth century, and the legal status of trained midwives was the same in both

\footnotetext{
${ }^{18}$ Betänkande med utredning och förslag angående barnmorskeväsendet avgivet av 1941 års barnmorskeutredning, SOU 1942:17, Stockholm, Socialstyrelsen, 1942, p. 13.

${ }^{19}$ Förlossningsvårdens organisation, Socialstyrelsen redovisar, no. 35 , Stockholm, Socialstyrelsen, 1973.

20 The Swedish development in hospital deliveries is almost parallel to the development in the USA. See Loudon, op. cit., note 1 above, pp. 274-5, and Judith Waltzer Leavitt, Brought to bed: childbearing in America, 1750-1950, New York, Oxford
}

\begin{abstract}
University Press, 1986. There are some similarities between the USA and Sweden - both are sparsely populated countries, and both had a high proportion of the population living in the countryside during the first decades of the twentieth century. But I believe that the parallel change occurred because both countries strove to modernize society, believing in the possibilities of science to guide them, and because the changes in social life during this century were rapid and radical (see below, p. $189 \mathrm{ff}$ ).

${ }^{21}$ Marland, op. cit., note 17 above, p. 23.
\end{abstract}


The Change of Place of Birth in Denmark and Sweden

Figure 5: Home deliveries as a percentage of all deliveries in Sweden in 1934.

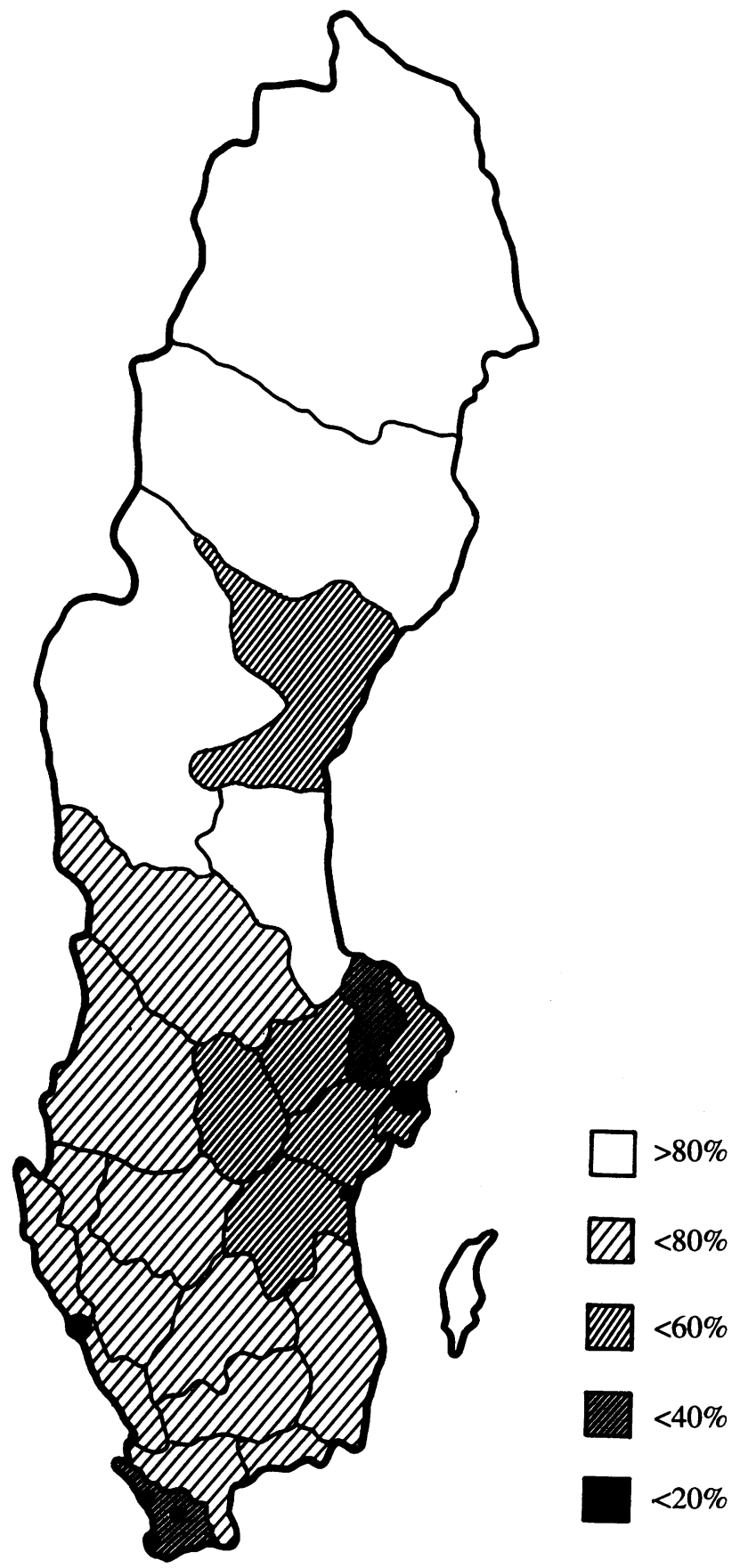

Source: Betänkande angående förlossningsvården och barnmorskeväsendet samt förebyggande mödra-och barnavård, SOU 1936:12, Stockholm, Socialdepartementet, 1936. 


\section{Signild Vallgårda}

Figure 6: Home deliveries as a percentage of all deliveries in Denmark in 1949.

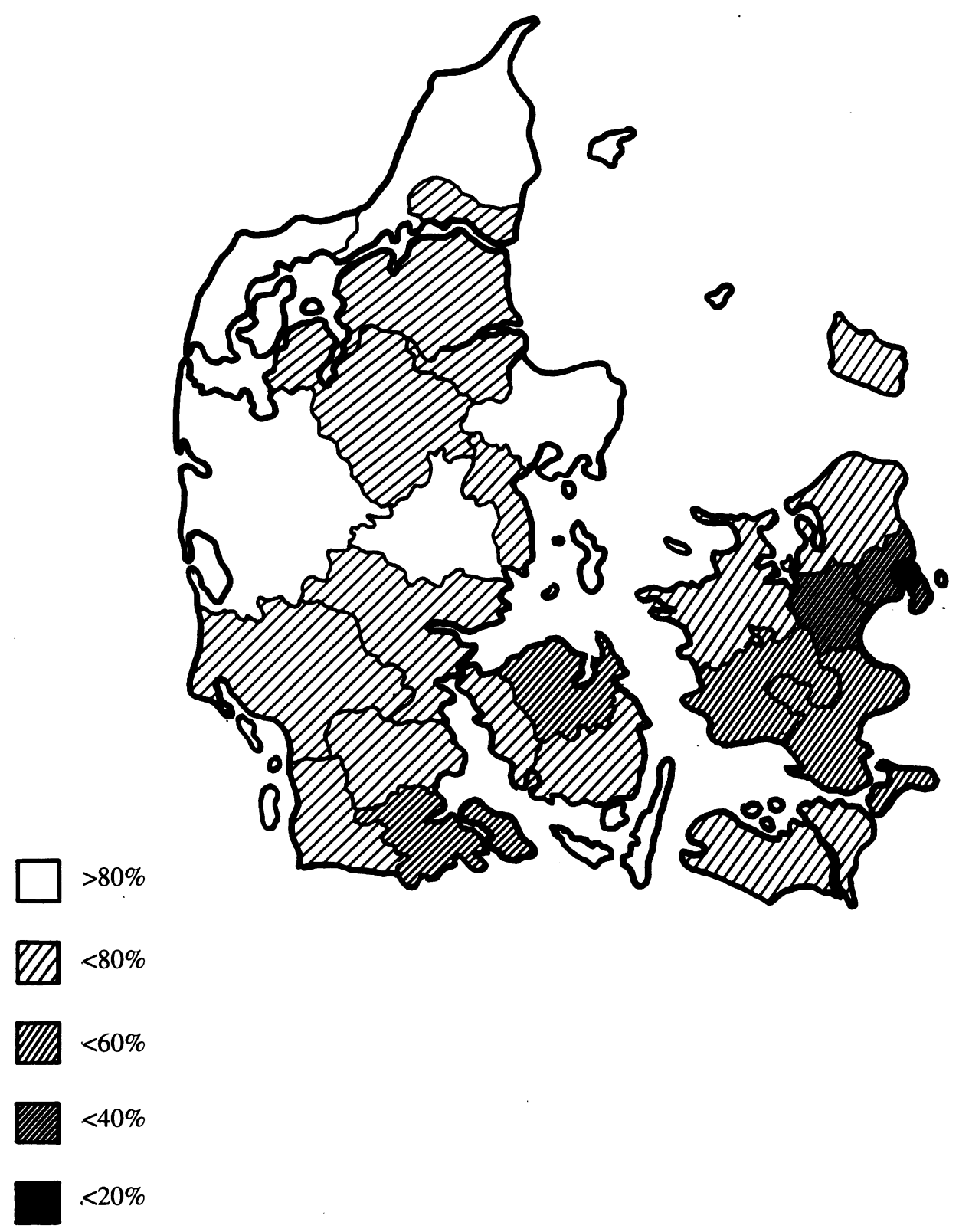

Source: Medicinalberetning for Kongeriget Danmark 1949, Copenhagen, Sudhedsstyrelsen, 1951. 


\section{The Change of Place of Birth in Denmark and Sweden}

countries. ${ }^{22}$ The first maternity hospitals were established at that time with the education of midwives as one of their central tasks. Some of the pupils attended the schools free of charge, others were paid for by the municipalities. Much of the training was practical. The theoretical education was given mainly by obstetricians. It was the duty of a trained midwife to be available to attend all deliveries; she would attend complicated deliveries with a doctor. ${ }^{23}$ Swedish midwives had a broader range of skills than their Danish colleagues. From 1829 they were entitled to use instruments, for example, forceps and instruments for embryotomy, provided they had passed a special examination. The right to use sharp instruments was abolished in 1919, but Swedish midwives sometimes still use the vacuum extractor. In the year 1900 almost 80 per cent of midwives had received such training. ${ }^{24}$ The training period for midwives was gradually extended. In Denmark it rose from six months in the late eighteenth century, to one year in 1895, two in 1927 and three in 1941. In Sweden a midwifery course lasted only three months at the beginning, this was extended in 1819 to six months, and in 1840 to nine months plus three months of instrument training. From 1921 the training lasted two years and in the 1940s the Swedish system changed so that midwifery training became a superstructure of nursing education. ${ }^{25}$ Neither in Sweden nor in Denmark did midwives experience real competition from general practitioners when assisting normal deliveries, as was the case in Great Britain and in the Netherlands. ${ }^{26}$ When in 1884, Leopold Meyer, a leading Danish obstetrician, suggested that doctors should attend all deliveries, the proposal was met with fierce resistance from both his colleagues and from midwives. ${ }^{27}$ Many doctors in both

\footnotetext{
22 Lundqvist, op. cit., note 6 above; Birger Lundqvist, 'Barnmorskeväsendet', in W Kock (ed.), Medicinalväsendet $i$ Sverige 1813-1962, Stockholm, Nordiska bokhandelns förlag, 1963, p. 645ff; Karin Johannisson, Medicinens öga. Sjukdom, medicin och samhälle, Stockholm, Norstedts förlag, 1990; Roger Qvarsell, Vårdens idehistoria, Stockholm, Carlssons, 1991; Signild Vallgårda, Sjukhus och fattigpolitik. Ett bidrag til de danska sjukhusens historia 1730-1880, Copenhagen, Fadls forlag, 1985. In the Netherlands clinical schools were set up in the 1820 s, but they had few pupils. It was not until 1861 that a state school was started in Amsterdam. In England the statutory recognition of midwives was established in 1902. Marland, op. cit., note 17 above, p. 27ff; Loudon, op. cit., note 1 above, p. 207; O Moscucci, The science of women. Gynaecology and gender in England 1800-1929, Cambridge University Press, 1993, p. 73.

${ }^{23}$ Cancelli Placat, Copenhagen, 29 Apr. 1791; Reglemente för Jorde-Gummorne, Stockholm, 14 Oct. 1777. The Swedish decision was overturned the year after with reference to the freedom of citizens. In 1819 it was put forward again. Betänkande om förlossningsvården, op. cit., note 8 above, pp. 7-8. In Norway, on the other hand, midwives and doctors should be called in only if the delivery became complicated, provided the distance or another reason did not make it impossible. 'Norsk lag om
}

jordemødre. 10/12 1898', in Betankning om

Jordemodervasenet, Copenhagen, Medicinalkommissionen, 1913; Rescript ang. naar nogen herefter skulde vilde paatage sig, Giordemødres forretning $i$ Kiфbenhavn og Christianshavn, Copenhagen, 30 March 1714; Instruks for samtlige til Praxis berettigede Jordem $\phi$ dre, Copenhagen, 28 Sept. 1877 and 25 Nov. 1896; Reglemente för Jorde-Gummorne, Stockholm, 14 Oct. 1777; Utdrag af Reglemente för

Barnmorskor, Stockholm, 25 Aug. 1819.

${ }^{24}$ Lundqvist, op. cit., note 22 above, pp. 697.

25 Helen Cliff, Jordemoderliv, Copenhagen,

Borgen, 1992, p. 27; Lundqvist, op. cit., note 22 above, pp. 651 .

${ }^{26}$ Marland, op. cit., note 17 above, pp. 30; Loudon, op. cit, note 1 above, pp. 206-23; Moscucci, op. cit., note 22 above, pp. 65-74.

${ }^{27}$ Leopold Meyer, 'Om en Udvidelse af Lægens Virksomhed som Fødselshjælper', Hospitalstidende, 1884, 3Rk, Bd II, p. 146; S Meyer, 'I Anledning af Dr. med. Leopold Meyer's Artikel: Om en Udvidelse af Lægens Virksomhed som Fødselshjælper', Hospitalstidende, 1884, 3 Rk, Bd II, p. 206; I Wegener, 'Nogle Betragtninger i Anledning af Dr. L. Meyers Artikel', Hospitalstidende, 1884, 3 Rk, Bd II, p. 317. See also, Anne Løkke, 'The antiseptic transformation of Danish midwives 1860-1920', in Marland and Rafferty (eds), op. cit., note 14 above. 


\section{Signild Vallgårda}

countries supported the midwives and helped them to organize professionally and to edit journals, as in the Netherlands. ${ }^{28}$ Thus there is no indication that lower professional skills or less independence amongst Swedish midwives caused the early decline in home deliveries in Sweden. The respected and independent role of the Dutch midwife has been put forward as an explanation for the continued use of home deliveries in the Netherlands. ${ }^{29}$ But in Sweden, where the midwives had, and preserved, an independent position and competence, hospital deliveries became common early on. Hospital deliveries, however, do not necessarily imply, nor are they necessarily caused by, the same changes in professional relationships in all countries.

\section{Availability of Doctors}

The possibility of summoning a doctor for assistance could be another factor influencing the choice of place of delivery. In the 1930s there were twice as many doctors per 1,000 inhabitants in Denmark as in Sweden, and a high percentage of Danish doctors were general practitioners (see Figure 7). Thus it was easier to receive help from a doctor for a home delivery in Denmark. Furthermore, general practitioners were evenly distributed over the whole country, mainly due to the contracts with the health insurance schemes, which reimbursed medical treatment by doctors to a much larger extent than in Sweden, see above. Danish doctors were very active in promoting the establishment of health insurance schemes, while Swedish doctors were indifferent towards them. ${ }^{30}$ In Sweden the distribution of doctors was uneven, with a concentration in the cities, and it is only recently that the country has reached the Danish level of physicians per 1,000 inhabitants. The availability of doctors and midwives in Denmark may have influenced some women living in the countryside to continue to give birth at home. Women in urban areas in Sweden, where doctors and midwives were more easily available, were, however, the first to go to hospital to give birth. A further investigation into rural/urban differences may be a useful way to pursue this question. Doctors could provide pain relief. Admittedly from 1944 Swedish midwives assisting at home births were provided with a transportable gas and air machine, ${ }^{31}$ but since at this time very few births took place at home in Sweden, it is unlikely this had an effect on the change of place of birth. Even in the 1950s Danish midwives were not allowed to handle these machines, probably because Danish doctors wanted to keep this task for themselves, and thereby the income from home birth attendance. Obstetricians worked mainly at the big hospitals, very few would assist at home deliveries in either country. Many smaller hospitals had only surgeons to assist at deliveries. The fact that there were doctors available to attend home deliveries may have facilitated continued home births in Denmark, while, before 1944, Swedish women had to go to hospital in order to get pain relief. In Denmark, the Netherlands and Britain the situation was similar, with fairly easy access to general practitioners. In Denmark,

\footnotetext{
${ }^{28}$ Marland, op. cit., note 17 above, p. 35; M J van Lieburg and Hilary Marland, 'Midwife regulation, education, and practice in the Netherlands during the nineteenth century', Med. Hist., 1989, 33: 296-317. See also, Løkke, op. cit., note 27 above.

${ }^{29}$ Torre and Reich, op. cit., note 9 above; Marland, op. cit, note 17 above, pp. 23. For an interesting
}

analysis of the background for the position of the Danish midwife see Løkke, op. cit., note 28 above.

${ }^{30}$ Ito, op. cit., note 10 above, p. 14.

${ }^{31}$ Lundquist, 'Barnmorskeväsendet', op. cit., see note 22 above, p. 651 . 
Figure 7: Number of doctors per 1,000 inhabitants 1880-1970.

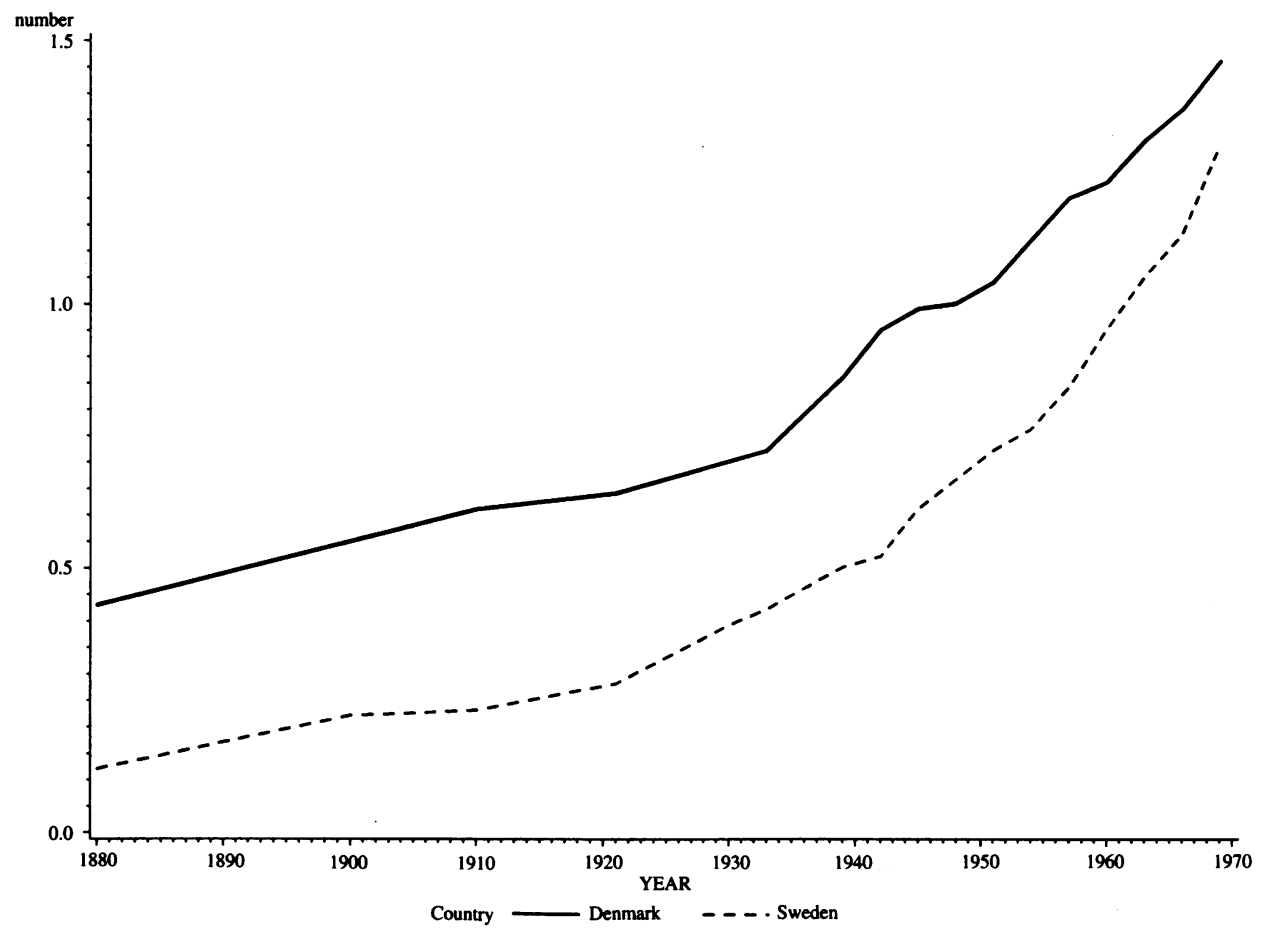

Sources: S Vallgårda, Sygehuse og sygehuspolitik i Danmark. Et bidrag til det specialiserede sygehusvaesens historie 1930-1987, Copenhagen, DJØFS forlag, 1992; Allmän hälso-och sjukvård. Medicinalstyrelsen, Stockholm, Socialstyrelsen, annual publication.

however, the general practitioners hardly ever attended normal deliveries alone without a midwife.

\section{Hospitals and the Specialty of Obstetrics}

A large number of hospital beds in Sweden would explain the earlier trend towards hospital deliveries, but Sweden did not have more hospital beds per 1,000 inhabitants than Denmark (see Figure 8). The rise in the number of hospital beds was parallel. This means that in Sweden beds were used for maternity purposes, whereas in Denmark they were used for other groups of patients. There is no reason to believe that there was a corresponding variation in health status, creating a greater "need" for hospitalization for parturient women or a reduced need for other patient groups in Sweden. Parturient women were given priority in Sweden at the expense of others.

It is often maintained that the development of medicine in itself is a determining factor for the specific organization and activities of health care. ${ }^{32}$ If in Sweden the specialty of

\footnotetext{
32 For examples see Signild Vallgårda, Sygehuse og sygehuspolitik i Danmark. Et bidrag til det specialiserede sygehusvoesens historie 1930-1987,
} Copenhagen, DJØFs forlag, 1992, pp. 106, 111, 158, 


\section{Signild Vallgårda}

Figure 8: Hospital beds per 1,000 inhabitants in Denmark and Sweden.

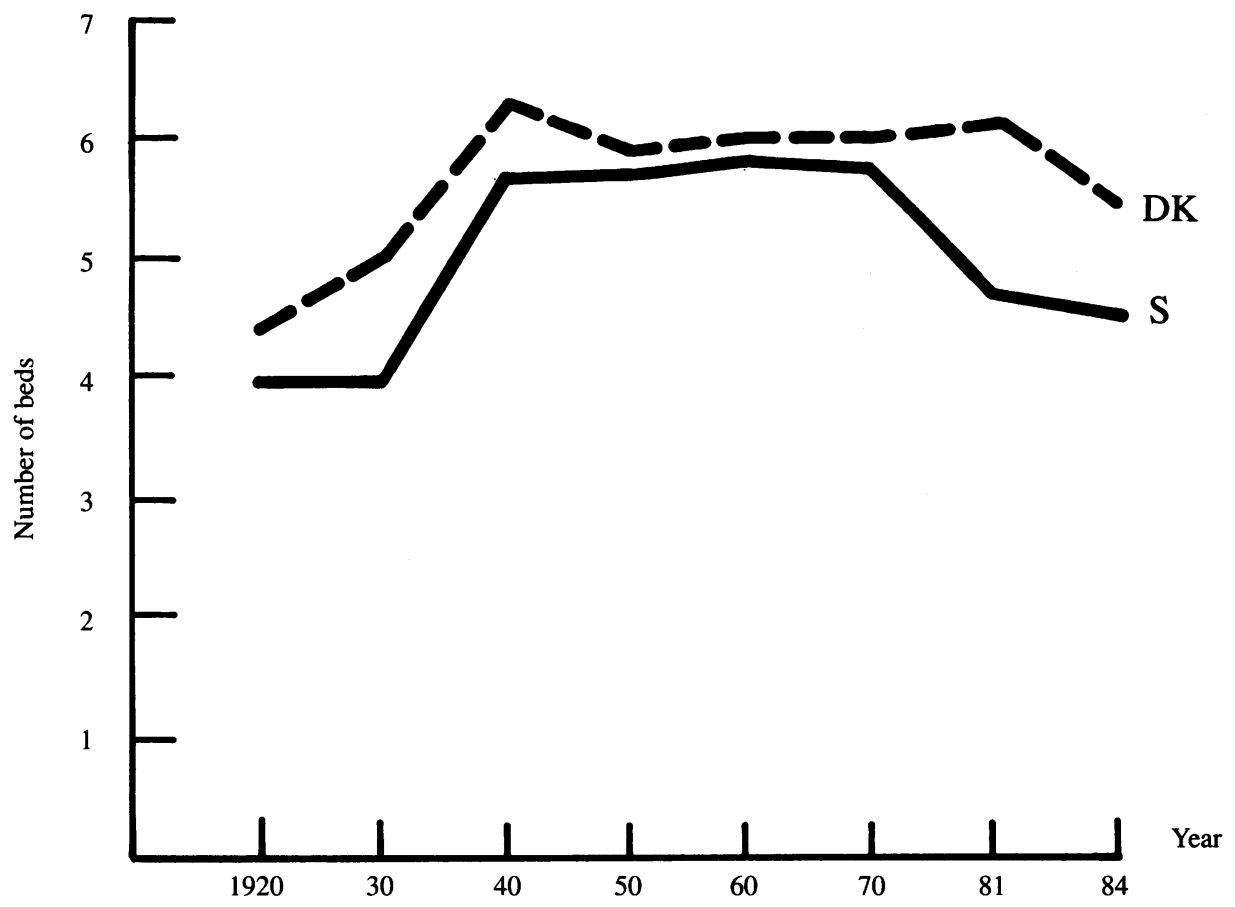

Sources: S Vallgårda, Sygehuse og sygehuspolitik i Danmark. Et bidrag til det specialiserede sygehusvasens historie 1930-1987, Copenhagen, DJØFS forlag, 1992; Allmän hälso-och sjukvård. Medicinalstyrelsen, Stockholm, Socialstyrelsen, annual publication.

obstetrics could be said to be more developed with respect to scientific status, this could be a factor contributing to hospitalization. Obstetrics was mentioned at an early stage as a speciality in Swedish hospitals, while this was not the case in Denmark. This could indicate both the stronger position of Swedish obstetricians and the higher priority given to child-bearing women. The history of obstetrics in the two countries has not yet been investigated, but some indications of it can be given. In both countries, obstetrics was taught at the medical faculties from the eighteenth century, and students were given the opportunity for clinical practice at the established maternity hospitals. The first professors in obstetrics in Copenhagen and Stockholm were appointed in the same year, 1761. Outpatient clinics for pregnant women were established at the university hospitals in Copenhagen and Stockholm in the 1920s. The extent of scientific activity is difficult to judge. Acta Scandinavica Gynaecologica-Obstetrica was published from 1922, and a Scandinavian scientific society began in 1933. The focus of interest in obstetric research has, however, differed somewhat, with more research into eclampsia in Sweden and into pregnant diabetics in Denmark. Generally, there is no reason to believe that knowledge established in one of the countries was not swiftly transferred to the other, and that the development of obstetrics as such can explain the hospitalization of deliveries.

Among the characteristics of the health care sector it has only been possible to identify the early supply and availability of midwives, and the higher number of doctors and 
thereby the access to pain relief, as a partial explanation of why home deliveries persisted so much longer in Denmark.

\section{Ideas and Motives}

The organization of health care results from the activities of different groups and constitutes some of the conditions for their actions. To understand why the groups involved acted as they did, their ideas, motives, and arguments for and against home deliveries are analysed.

\section{Midwives}

In Denmark as well as in Sweden midwives opposed hospital confinements for all women. ${ }^{33}$ Fewer midwives were needed for hospital births than for the same number of home deliveries, and the change of place of birth was therefore seen as a threat to their employment. It is likely that this was the most important motive for their resistance. In hospitals, their autonomy would be reduced and, although doctors were not necessarily present at every delivery, the norms and standards were set by the consultant. Some Swedish midwives also opposed what they called the factory-like character of hospital confinements. ${ }^{34}$ According to two Swedish obstetricians, the opposition among Swedish midwives was more widespread than one understands from reading their journal. ${ }^{35}$ It is not possible to detect a difference in ideas between midwives from the two countries.

\section{Doctors}

Danish general practitioners, who received part of their income from home deliveries, therefore opposed hospital deliveries. ${ }^{36}$ As mentioned, the number of general practitioners was much higher in Denmark than in Sweden and they were better established as a group. This meant that they had greater influence than Swedish general practitioners. Although they were not the most influential group within the medical association, which organized practically all Danish doctors, they constituted half of the medical profession in the early 1930s.

Obstetricians in both countries preferred hospital deliveries to home deliveries for two reasons: hospital deliveries gave women a greater feeling of security, and they reduced morbidity and mortality among women and neonates. The hospitals also gave the doctors a feeling of security. "I always felt it unpleasant leaving my well-equipped ward and experienced midwives" to attend a home birth with an unknown midwife, a Swedish

\footnotetext{
${ }^{33}$ Betänkande angående, op. cit, note 8 above, pp. 12ff; F Fiehn, 'Fødselsforhold', Tidsskrift for Jordem фdre, 1923, 33: 127-37; 'Stockholms barnmorskor och allmänna barnbördshuset', Jordemodern, 1913, 26: 200.

${ }^{34} \mathrm{G}$ Aurell, 'Några ord om den tilltagande benägenheten att förlösas utanför hemmet', Jordemodern, 1927, 40: 172.
}

\footnotetext{
35 Otto Gröné, 'Något om barnmorskorna och barnbördshusen', Läkartidningen, 1949, 4: 2564; L Simon, 'Hemförlossning kontra anstaltsförlossning', Läkartidningen 1963, 60: 3528.

${ }^{36}$ A Gullestrup, 'Konfelater, udefødsler og sund fornuft', Ugeskrift for lager, 1956, 118: 1476-8; A J Buntzen, 'Om konfelater, udefødsler og sund fornuft', Ugeskrift for lager, 1956, 118: 1534-5.
} 


\section{Signild Vallgårda}

doctor wrote in retrospect in $1963 .{ }^{37}$ A common view expressed by both Danish and Swedish obstetricians was that all women ought to give birth in hospitals, preferably in obstetric departments. ${ }^{38}$ Before the Second World War, the issue was, however, hardly discussed among doctors in Denmark; why this was the case is difficult to tell. Unexpected risks were often used as arguments favouring hospital deliveries in both countries. In 1956 a Danish government report read: "Many, especially many serious and life-threatening birth complications . . . appear suddenly . . . At the hospital, doctors and technical equipment are immediately available ..."39 And earlier, in 1936 in Sweden: "Unexpected complications, which can appear even in minor obstetrical interventions, are of course much easier handled in a hospital than at home." 40 Thus the opinions of doctors were contradictory, at least in Denmark, depending on whether they were those of obstetricians or general practitioners. Opposition came from doctors attending home deliveries, the number of which was much higher in Denmark.

\section{Women}

It is obvious that Swedish women changed their habits regarding the place of birth at an early period. In Sweden during the 1920s and 1930s hospital maternity wards were filled to overcapacity. ${ }^{41}$ Women changed their habits not only because maternity clinics were provided, i.e., it was not only a supplier-induced demand for hospital care. One can therefore assume that one of the reasons why local politicians provided maternity care in hospitals was in answer to demands from many women.

We have very little evidence of the ideas and motives of women in this regard. The study of several decades of women's journals, both political and popular, has resulted in almost no findings. Giving birth has for some peculiar reason not been a subject that preoccupied women's organizations or journalists. The reason for going to hospital most likely varied according to social class. In Sweden in the early 1940s midwives were asked by a government commission about women's reasons for going to hospitals or maternity homes. ${ }^{42}$ According to the midwives, the cost of paying the travel expenses of the midwife to and from home was important. These increased as the districts grew larger. Scarcity of midwives and insufficient postnatal care were also mentioned as factors, as were the possibility of obtaining pain relief at the hospitals, the difficulty of receiving help when at home, and the fact that husbands wanted their wives to go to hospital. ${ }^{43}$ Overcrowding at home was seldom mentioned by the women themselves, but was brought up by the midwives. These reasons listed by midwives may of course have been coloured by their

37 Simon, op. cit., note 35 above, p. 3527.

38 Betankning II, op. cit, note 8 above, p. 38; Mogens Ingerslev, 'Hospitaliseringsbehovet', Nordisk Medicin, 1962, 68: 1049.

${ }^{39}$ Betankning II, op. cit., note 8 above.

40 Betänkande angående, op. cit., note 8 above, p. 13. See also, E Essen-Möller, 'II. Några ord om den tilltagande benägenheten att förlösas å barnbördshus', Jordemodern, 1927, 40: 193-6; Otto Gröné, 'Barnbördsvården enligt statens sjukvårdskommités förslag', Jordemodern, 1935, 48: 4-16.
${ }^{41}$ Betänkande om förlossningsvården, op. cit., note 8 above, p. 82; A Wallentheim, 'Förhållanden ofta olidliga på BB-avdelningarna', Morgonbris, 1944, no. 4, pp. 21-2.

42 Betänkande om förlossningsvården, op. cit., note 8 above, p. 12.

${ }^{43} \mathrm{G}$ Aurell, 'III. Några ord om den tilltagande benägenheten att förlösas å barnbördshus',

Jordemodern, 1927, 40: 196-8, confirms this point about the husbands' wishes. 


\section{The Change of Place of Birth in Denmark and Sweden}

professional views and interests. Pain relief, the feeling of security, and overcrowding were the reasons most often given in Swedish government reports and by doctors as to why women wanted hospital deliveries. ${ }^{44}$ In Denmark as well, overcrowding, the need for peace and rest, and the demand for security in the case of complications were mentioned in a government report of 1938 as being the reasons why women went to hospital to give birth. ${ }^{45}$ No arguments for giving birth at home were given in the sources, but since that was what was considered "normal" and hospital deliveries were a new phenomenon, it was the latter which should be encouraged. Although most of these statements were made by politicians and public officials, I believe they contain a key to the understanding of women's change in behaviour. The recurring issue of the higher feeling of security in hospitals can provide a clue to these changes.

According to anthropologists, transitional events, such as births, initiations, and deaths, involve rituals in most societies. ${ }^{46}$ Rituals, the setting, the persons involved, and the acts performed have meaning in accordance with the ways people interpret the world and their experiences. This interpretation can be religious, technological, medical, etc. A possible explanation for women's changing habits could be that their social lives created a need for new rituals surrounding decisive events in their lives such as birth. This new attitude could be due to different living conditions caused by urbanization, industrialization, and the emergence of new social classes ${ }^{47}$ and to new ideas about the role of science, technology, and hygiene, etc. The rituals surrounding deliveries at hospitals got their meaning from a scientific view of the world which assumed that man through technology could control nature. ${ }^{48}$ It was women in urban areas who started the movement towards hospital confinements, and it was their way of life which differed most from previous life styles. In 1936 as many as 75 per cent of deliveries in Copenhagen took place outside women's homes. The fact that the home continued to be the most common place of birth in rural areas and that hospital deliveries became common in the big cities at an early point in time thus

\footnotetext{
${ }^{44}$ Betänkande angående, op. cit, note 8 above, p. 8; Betänkande med utredning, op. cit, note 18 above, p. 10; Gröné, op. cit., note 35 above, p. 2560; Simon, op. cit., note 35 above, p. 3529; Betänkande om förlossningsvården, op. cit, note 8 above, p. 83ff.

45 Betankning afgivet af befolkningskommissionen af 1935 angaaende Moderens Rettigheder $i$

Anledning af fødsel samt angaaende

Seksualoplysning, Copenhagen,

Befolkningskommissionen, 1938, p. 95-101.

46 Rituals surrounding births in early modern

Europe have been described by Jacques Gélis,

History of childbirth. Fertility, pregnancy and birth

in early modern Europe, London, Polity Press, 1991.

He does not, however, seem to consider modern birth attendance as a set of rituals: age-old values have disappeared with the industrial revolution "without offering anything in their place", p. 96.

47 Jonas Frykman, Orvar Löfgren, 'På väg - bilder av kultur och klass', in Jonas Frykman, Orvar Löfgren (eds), Modärna tider. Vision och vardag $i$ folkhemmet, Lund, Liber förlag, 1985; Åke Elmér, Från Fattigsverige till välfärdsstaten, Stockholm, Aldus/Bonniers, 1963.
}

\begin{abstract}
48 This accords with B Jordan's view: "It is not 'scientific' evidence which provides the major impetus for change, but rather perturbations and adjustments in the social, intellectual, and political structure with which the birthing system articulates." See B Jordan, Birth in four cultures, Montreal, Eden Press, 1981, p. 66. I would, however, not reduce the influence of scientific changes to zero. On the ritual characteristics of hospital deliveries see R Davis-Floyd, 'The role of obstetrical rituals in the resolution of cultural anomaly', Social Sci. Med., 1990, 31: 175-89. Some points are also made by $\mathrm{P}$ Lomas, 'An interpretation of modern obstetric practices', in S Kitzinger, J A Davis (eds), The place of birth, Oxford University Press, 1978. See also, Eli Heiberg Endresen, 'For sikkerheds skyld. Rutiner og ritualer i svangerskabskontrollen', thesis, University of Oslo, 1986. The suggestion is supported by a Danish obstetrician, M Osler, who wrote: "Furthermore the increasing urbanization played a role both for the population and the midwives. The general change in living conditions may also in different ways be assumed to have had an influence." 'Jordemodervæsenet og svangreprofylaksen', Bibliotek for lager, 1973, 165: 83-90.
\end{abstract}




\section{Signild Vallgårda}

runs parallel to the spread of trained midwives in the nineteenth century, at least in Sweden. ${ }^{49}$ Unlike women in rural areas, women in towns and cities lived in new conditions. It is therefore likely that they needed new social patterns and rituals when giving birth. Access and distance to midwives and hospitals also influenced women's choices.

The hypothesis that emerges from this is that the rapid change in living conditions experienced by women created a need for new rituals in connection with the decisive event of confinement. The fact that change in Sweden was both more rapid and radical could be a reason why the move towards hospital deliveries was faster there. It may not be possible to substantiate this hypothesis, considering the fallibility of oral sources, the fact that the majority of women who gave birth during the interwar years are now dead, and that they were most likely not conscious of the choice they were making. The example of countries like England and the Netherlands which experienced urbanization and industrialization much earlier without a simultaneous change in birth rituals might undermine this idea, but the changes there were neither as rapid nor as radical as in Sweden. Another factor could have contributed to the change in Sweden. This was the development of a strong trust in the ability of science to find solutions to a variety of problems, which coincided with the social changes in Sweden and the endeavours of large popular movements to alter the old ways of life.

\section{Politicians}

Politicians can favour a specific place of delivery through finance and regulation. Their ideas and motives for these decisions are thus important for understanding the changed conditions.

In Denmark home deliveries had been free of charge earlier than in Sweden and for a higher proportion of the population. In Sweden all birth attendance was made free in 1938, irrespective of the place of birth. At the same time, state subsidies were provided to establish maternity homes and maternity departments in hospitals. At this time, however, more than half the women gave birth in hospitals. The changed financing may have strengthened the trend towards hospital confinements, but the change had begun long before as a consequence of decisions made by women, doctors, and local politicians. Before 1938, hospital deliveries were more expensive than home deliveries, at least for members of health insurance schemes. In Denmark, state subsidies for bed days in connection with normal deliveries were given as late as in 1961. State subsidies were given to Danish hospitals in accordance with the number of bed days provided. In 1952, a central board, Sygehusrådet, stated that state subsidies should not be given for bed days in connection with normal deliveries. ${ }^{50}$ Many counties, however, had previously let women give birth at hospitals free of charge, provided they were members of a health insurance scheme. ${ }^{51}$ Why did Swedish politicians support maternity institutions so early? There were of course several reasons.

The first was the issue of social policy. There was an interest in providing a good birth environment for those women whose home conditions were bad. In 1914 an investigation

\footnotetext{
${ }^{49}$ Brändström, op. cit., note 14 above, pp. 56-67.

50 P Lange, K A Møller, 'Udviklingen af det gynækologisk-obstetriske speciale inden for sygehusvæsenet i relation til lovgivningen', Bibliotek for lager, 1973, 165: 105-11.
}

\footnotetext{
51 Betankning II, op. cit, note 8 above, p. 9; Betankning afgivet, op. cit., note 45 above, p. 97.

52 G Steenhoff, 'Förlossningshem', Läkartidningen, 1923, 20: 97-102.
} 
initiated by the Riksdag (Parliament) among 14,000 poor childbearing women showed they lived in very unhealthy surroundings. ${ }^{52}$ The Red Cross and some municipalities established small maternity homes to give these women an opportunity of having a calm and clean place to give birth. These institutions were not initially established to give them access to medical help. The social aspect also continued to play a role. In 1936 a government report stated that the question of maternity clinics was a "most important social issue" and that they should also be available to women not having complicated births ${ }^{53}$ In 1933 the Danish social policy reform contained a request to counties and municipalities to establish maternity homes especially for poor women. The request was not fulfilled.

A second issue was population policy. During the first decades of the century, Swedish politicians were very concerned about the low level of population growth. ${ }^{54}$ This had two causes: huge emigration, mainly to the United States, and a declining birth rate. Both phenomena were seen in Denmark as well as in other European countries, but not to the same extent (see Figure 9 for the total fertility rate). Population increase was thus much

Figure 9: Total period fertility rate in Denmark and Sweden.

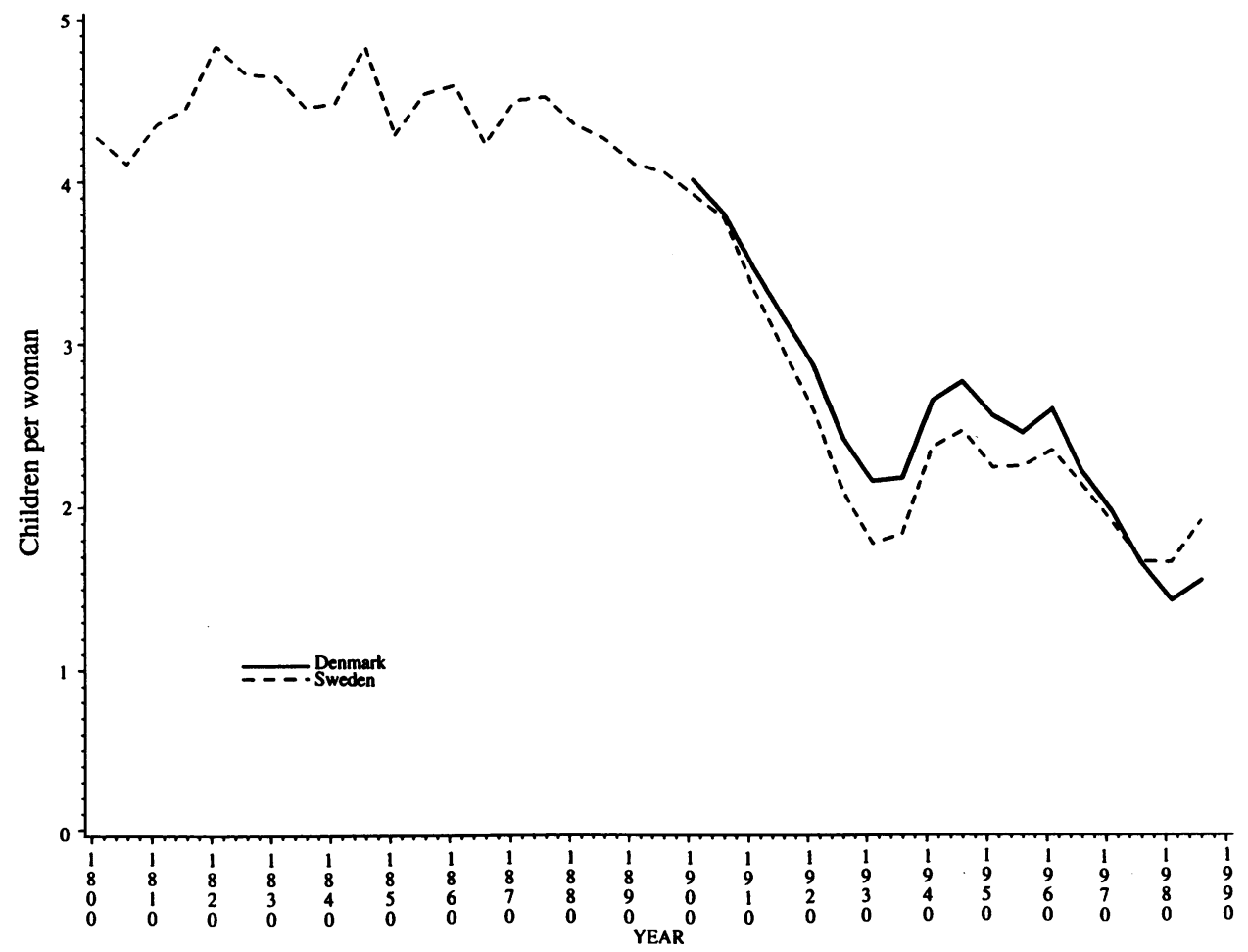

Sources: Befolkningens bevagelser, Copenhagen, Danmarks statistik, annual publication; Befolkningsrørelsen, Stockholm, Statistiska Centralbyrån, annual publication;

Befolkningsudvikling og sundhedsforhold 1901-1960, Copenhagen, Det statistiske departement, 1961; Historisk statistik för Sverige, vol. 1, Stockholm, Statistiska Centralbyrån, 1969.

${ }^{53}$ Betänkande angående, op. cit., note 8 above, p. 10.

54 Ibid., p. 7; Slutbetänkande avgivet av befolkningskommissionen, SOU 1938:57, Stockholm, Socialdepartmentet, 1938. 


\section{Signild Vallgårda}

slower in Sweden. Between 1900 and 1930 it rose only 20 per cent, as compared with 45 per cent in Denmark.

The provision of maternity clinics was presented in government reports from the 1930s and 1940s in Sweden as a measure intended to counteract this demographic development in two ways. If women preferred to give birth in hospitals, they should have the opportunity to do so, because that could encourage them to have more children. ${ }^{55}$ The committee set up to look at the population issue suggested offering free maternity care and subsidies for maternity clinics. ${ }^{56}$ As mentioned earlier, women went to hospital to give birth to an extent which was beyond the capacity of the maternity wards, indicating a high demand for these services.

Another reason mentioned in the reports was that hospital confinements could result in reduced morbidity and mortality among mothers and children. Swedish infant mortality was low compared with other countries, but the regional and social differences were substantial, indicating that a further reduction was possible. Two conflicting arguments emerged. One assumed that improved medical technology could contribute to a decline in mortality. This was the line taken mainly by doctors and the Swedish National Board of Health. It was said that if a hospital had technical equipment, trained doctors and midwives to help in the case of complications, an increased number of hospital deliveries should lead to a reduction in infant mortality. ${ }^{57}$ In 1936 the National Board of Health wrote:

Obviously deliveries at hospitals, where doctors are always available and the technical possibilities of the medical institutions can be used without delay, result in certain advantages for both mother, fetus and the newborn child. ${ }^{58}$

The second line of argument maintained that if in fact hospital confinements did lead to reduced mortality, the mortality rates would show this. Since there had been no reduction in the perinatal mortality rate during the years when hospital confinements became common, there was no reason to believe that further hospitalization would lead to a reduction in the mortality rates. A government report stated:

The fact that, in spite of an increase in hospital capacity, no manifest reduction in mortality in connection with confinements has been seen during the last decades, does not support the idea that hospitalization for all child-bearing women would contribute to the reduction of that risk..$^{59}$

This idea got further support at a medical meeting in 1942, where a doctor presented figures showing a slightly increasing perinatal mortality rate (see Figure 10 ) ${ }^{60} \mathrm{He}$ explained that the rise

\footnotetext{
55 Kungliga medicinalstyrelsens utlåtande och förslag angående förebyggande mödra- och barnavård, SOU 1935:19, Stockholm, Socialdepartementet, 1935; G Forsell, 'Nativitet, humanitet och förlossningsvård', Socialmedicinsk tidsskrift, 1944, 21: 143-7; Alva and Gunnar Myrdal, Kris $i$ befolkningsfrågan, Stockholm, Albert Bonniers förlag, 1934, p. 103.

56 Betänkande angående, op. cit., note 8 above, p. 7.

57 Simon, op. cit., note 35 above, p. 3528. The same type of argument appeared later in Denmark. Betankning II, op. cit., note 8 above.
}

\footnotetext{
${ }^{58}$ Betänkande angående, op. cit., note 8 above, p. 13. The translations of quotations from this report are mine.

59 Ibid., p. 10.

${ }^{60} \mathrm{C}$ Gyllenswärd, 'Orsakerna till dödfdöddhetens och tidigdödlighetens stigande i Sverige under de senaste åren', in J P Edwardson (ed.), Förhandlingar vid tjugutredje allmänna läkarmötet, Karlshamn, 1942, p. 84. See also, Signild Vallgårda, 'Trends in perinatal death rates in Denmark and Sweden, 1915-1990', Paediatr. perinatal Epidemiol., 1995, 9: 201-18.
} 
Figure 10: Perinatal mortality rates in Denmark and Sweden.

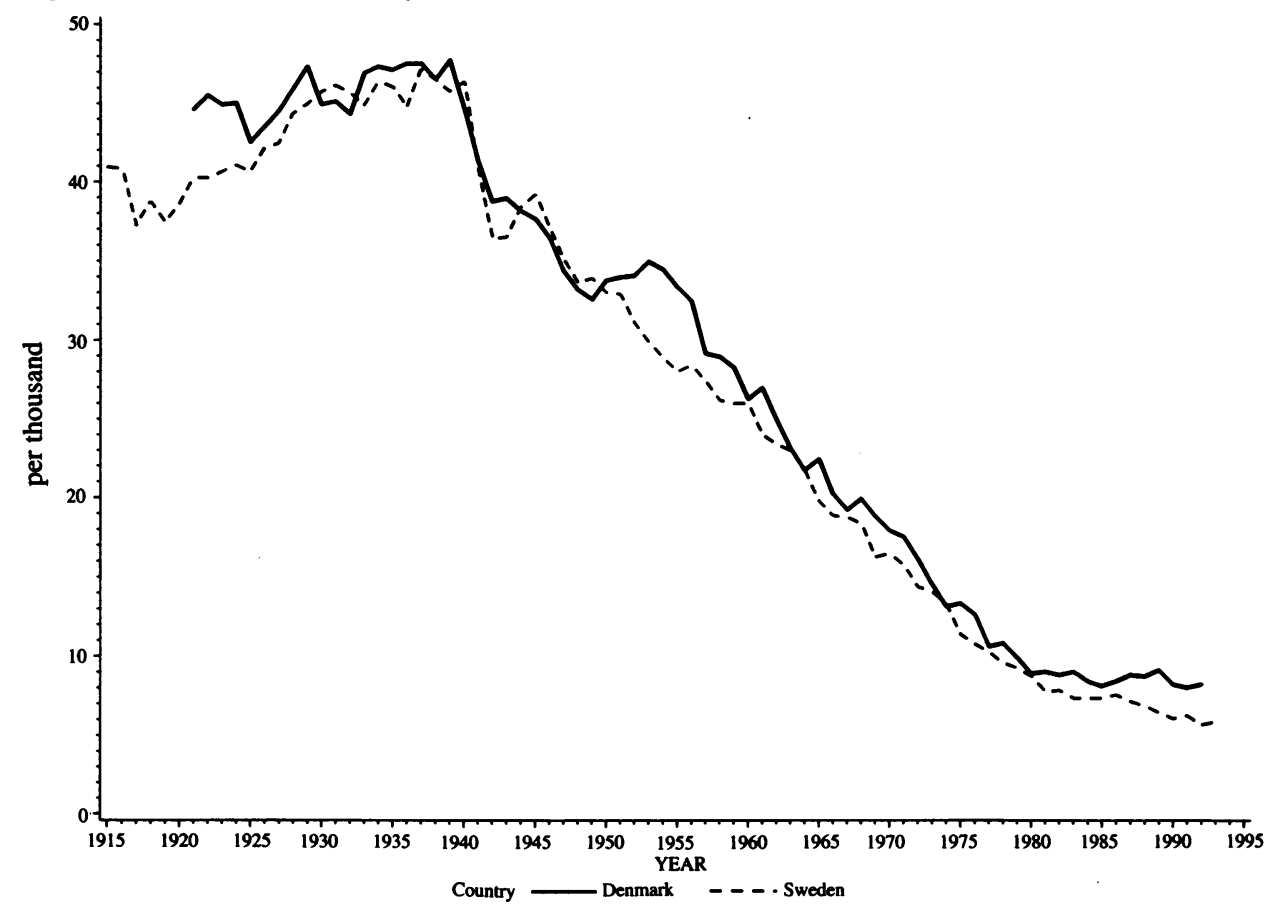

Source: S Vallgårda, 'Trends in perinatal death rates in Denmark and Sweden, 1915-1990', Paediatr. perinatal Epidemiol., 1995, 9: 201-18.

resulted from the increased hospitalization of normal births, above all caused by the long distances women in labour had to travel. There was thus no empirical evidence that hospitals contributed to a lower perinatal mortality rate, nevertheless, this did not prevent many doctors and others from believing that they did. A government report in 1936 argued against hospitalization of all deliveries: "A delivery is, under normal circumstances, not equivalent to a disease .. . experience shows that, without any risk for the woman, it can take place in her own home."

The same arguments were presented by the Danish population committee, set up in 1935 in order to find measures to improve the quantity and quality of the population. On the very same page they stated: "mortality for mothers and children . . . could [not] be reduced very much further" and "complications, which can appear during any delivery, can more easily and more safely be treated at a hospital, preferably in an obstetric ward."62 The concern about infant mortality was strongest in Denmark, whose mortality rate was the highest in Scandinavia.

The population policy, however, was concerned not only with the size of the population, but also with improving the quality; this could be achieved by preventing the birth of potentially undesirable members of society (such as criminals and alcoholics, as well as the mentally or physically handicapped). ${ }^{63}$ During the first decades of the twentieth

${ }^{61}$ Betänkande angående, op. cit., note 8, p. 10.

62 . Betankning, op. cit., note 45, p. 95.

${ }^{63} \mathrm{G}$ Broberg, M Tydén, Oönskade i folkhemmet, Stockholm, Gidlunds, 1991; Yvonne Hirdman, Att lägga livet till rätta - studier $i$ svensk folkhemspolitik, Stockholm, Carlssons, 1989, p. 145; Alva and Gunnar Myrdal, op. cit., note 55; Lene Koch, 'The biological aspect', in Lisbeth Andersen Skov (ed.), 


\section{Signild Vallgårda}

century, eugenics had a strong position among doctors and politicians in both countries, not least among the Social Democrats. More education in child care and better nutrition would also contribute to an improvement. ${ }^{64}$ In Sweden especially, several organizations (most founded in the late nineteenth century) worked to change the habits of the population. One of them was the temperance movement, which was almost non-existent in Denmark, ${ }^{65}$ others were the hygienic movement, ${ }^{66}$ and the sports movement. Old habits should be eradicated and replaced by more hygienic, educated, and disciplined behaviour. The labour movement also participated in these efforts, encouraging its members to gain respect and to achieve the other goals put forward. ${ }^{67}$ Thus in many areas of Swedish society there was an endeavour to create something new and modern and to repudiate the old in order to make Swedes richer, more hygienic, and more guided by scientific knowledge. These movements should consequently not only be seen as an attempt by the upper classes to change working-class life style, but also as a means for the working class to improve their position and to gain respect. It is, however, not the purpose of this article to investigate, ${ }^{68}$ why many of these movements for change were stronger in Sweden than in Denmark where the working class was much more traditional. ${ }^{69}$

In Sweden, more so than in Denmark, there was a strong belief that the state was entitled to change, and was actually capable of changing, the way the working class lived. ${ }^{70}$ Such intervention had a long tradition in Sweden. ${ }^{71}$ There was a belief that through scientific research one could find the right way to live and to teach others how to live. ${ }^{72}$ Trust in science, progress, rationality and general education had been strong among Radical Swedish intellectuals since the $1880 \mathrm{~s},{ }^{73}$ and was especially so in the $1930 \mathrm{~s}$ among intellectual Social Democrats. The best known exponents of these views were Alva and Gunnar Myrdal, whose widely read book on the population issue, Kris $i$ befolkningsfrågan ('Crisis in the population problem'), stated: "Bad habits must be corrected. The ignorant enlightened. The irresponsible awakened. There is room for people to be extensively informed and for propaganda organized by society." "Pure rationality may frighten some as being chilly. It can, however, only be a question of time before family problems can be

Rescue-43. Xenofobia and exile, Copenhagen, Munksgaard, 1993; Karin Johannisson, 'Folkhälsa.

Det svenska projektet från 1900 till 2:a världskriget',

Lychnos, 1991, pp. 139-95.

64 Slutbetänkande avgivet av

befolkningskommissionen, SOU 1938:57, Stockholm, Socialdepartementet, 1938, p. 42.

65 Sidsel Eriksen, 'Vækkelse og afholdsbevægelse. Et bidrag til studiet af den svenske og den danske folkekultur', Scandia, 1988, 54: 251-95.

66 Eva Palmblad, Medicinen som samhällslära, Göteborg, Daidalos, 1990; K Jonsson, 'En nybadad renrasig svensk på ett . . .' in I framtidens tjänst. $U r$ folkhemmets idéhistoria, Malmö, Gidlunds, 1986.

${ }^{67}$ Ronny Ambjörnsson, Den skötsamme arbetaren. Idéer och ideal $i$ ett norrländskt sågverkssamhälle 1880-1930, Stockholm, Carlssons, 1988; Elmér, op. cit., note 47 above.

${ }^{68}$ In an interesting article, Sidsel Eriksen (op. cit., note 65 above) explains the strength of the temperance movement in Sweden as being due to the influence of Anglo-American religious movements, where the improvement of one's own and others' life styles was an important task. Lutheranism in Denmark held that faith was a gift of grace and thus not obtainable through actions, and this attitude dominated the religious movements of the nineteenth century.

${ }^{69}$ Niels Finn Christiansen, Hartvig Frisch mennesket og politikeren. En biografi, Copenhagen, Christian Ejlers Forlag, 1993.

${ }^{70}$ Arbetarrörelsens efterkrigsprogram. Sammanfattning i 27 punkter, 1944, p. 17.

${ }^{71}$ Tim Knudsen, 'State-building in Scandinavia: Denmark in a Nordic context', in Tim Knudsen (ed.), Welfare administration in Denmark, Copenhagen, Institute of Political Science, 1991, pp. 14-20.

72 Ron Eyerman, 'Rationalizing intellectuals', Theory and society, 1985, 14: 777-807.

${ }^{73}$ Gunnar Aspelin, 'Tidsidéer och tidsideal', in Johan Cornell (ed.), De 50 åren - Sverige 1900-1950, vol. 3, Stockholm, 1950. 
treated technically and rationally." 74 Intellectual Social Democrats expressed these ideas very emphatically, with the aim of changing society from being backward, rural, filthy, superstitious and irrational to being clean, rational, scientifically organized, industrial and urban. ${ }^{75}$ In one of their manifestos, they called the first type of society B-Europe, and the second A-Europe. "With the help of horse-power, A-Europe has become the Europe of machines, banks, education and science, without them B-Europe has remained the Europe of agrarians, religious orthodoxy and illiterates."76 This modernization project involved all areas of society including the way people lived in their homes, carried out housework, and reared their children. In Denmark, on the other hand, at least among the leading Social Democrats, modernity was not seen as a positive value to strive for. ${ }^{77}$

Housing played a central role in this change. ${ }^{78}$ Standards of housing were low in Sweden and efforts to improve them date back to the late nineteenth century. ${ }^{79}$ The tradition of having a big kitchen, in which most of the family's activities took place, had been transferred from the countryside to towns and cities. The multifunctionality of these big kitchens was a thorn in the flesh of reformers, both from the Right and Left. They wanted separate areas for different functions; i.e., the kitchen ought to be small and used only for cooking. ${ }^{80}$ In government reports on the maternity question, overcrowding was often mentioned as a reason for women wanting to go to hospital to give birth, although, according to midwives, the women themselves seldom mentioned it. Overcrowding was no worse in the 1930s than at the beginning of the century, in fact the situation had improved due to falling birth rates. What can be seen here is a projection of the ideas of the middle and upper classes, especially the intellectuals. They certainly felt disgusted by the thought of confinements in small dwellings. In the modernization project, home births were seen as a remnant of the old way of living which should be abandoned. Hospital confinements, on the other hand, represented the new era: they were hygienic, scientific, and specialized. Hospital deliveries also provided the opportunity to teach women how to care for their babies, an argument especially favoured by doctors. ${ }^{81}$

For Swedish politicians hospital confinements were part of social and population policy (including both its quantitative and qualitative aspects). The fertility issue attracted

\footnotetext{
74 Alva and Gunnar Myrdal, op. cit., note 55 above, quoted in Hirdman, op. cit., note 63 above, pp. 123, 22.

75 Alva and Gunnar Myrdal, op. cit., note 55 above; I framtidens tjänst, op. cit., note 66 above; Eyerman, op. cit., note 72 above; Arne Ruth, 'The second new nation: The mythology of modern Sweden', Daedalus, 1984, 113: 77.

${ }^{76}$ Gunnar Asplund, et al., acceptera, Stockholm, 1931, p. 17.

77 Anders Linde-Laursen, 'Er Sverige interessant ... . Om modernitet og hundrede års danskhed', in A Linde-Laursen, J O Nilsson (eds), Nationella identiteter $i$ Norden - ett fullbordat projekt?, Copenhagen, Nordiska Rådet, 1991.

${ }^{78}$ Hirdman, op. cit., note 63 above; Roger Qvarsell, 'Brott och sjukdom. Psykiatri och visioner om ett rationellt samhälle', in I framtidens tjänst, op.
}

cit., note 66 above, pp. 126-47; Sverker Sörlin, 'Utopin och verkligheten. Ludvig Nordström och det moderna Sverige', in ibid., pp. 166-95; Asplund, et al., op. cit., note 76 above; Alva and Gunnar Myrdal, op. cit., note 55; Palmblad, op. cit., note 66 above.

${ }^{79}$ Kerstin Thörn, 'En god bostad för det riktiga livet. Den moderna bostadens ideologiska förutsättningar', in I framtidens tjänst, op. cit., note 66 above, pp. 196-213.

${ }^{80}$ Hirdman, op. cit., note 63 above. See also, Mary Douglas, Purity and danger. An analysis of the concepts of pollution and taboo, London, Routledge, 1992 , on the importance of separation and order.

81 Otto Gröne, 'Barnbördsvården enligt Statens sjukvårdskommité', Jordemodern, 1935, 48: 4-16; H Wickbom, 'Behovet av anstaltsvård, särskilt för ödemarksområdena', Jordemodern, 1937, 50: 363-8. 


\section{Signild Vallgårda}

political interest in Denmark as well, ${ }^{82}$ but it was not as intensely debated as in Sweden, probably because the decline in fertility was lower. Population policy (both the quantitative and qualitative aspects) played a role in Denmark, and in 1929 it was the first country to pass an Act on eugenic sterilization. ${ }^{83}$ There were also some efforts to educate the population on how to do housework, ${ }^{84}$ and how to rear children. ${ }^{85}$ But these efforts did not have the importance of the corresponding Swedish ones and were not conducted with the same strong ideology of modernization. The difference between the two countries lay in the emphasis placed on the population issue rather than in its content.

\section{Conclusion}

The different pace at which hospital confinements spread throughout the two countries can only to a minor extent be ascribed to differences in which health care was organized as a whole. The resources dedicated to health care were fewer in Sweden and the country was poorer. The midwives were well educated, respected and relatively independent in both countries. Neither the development of obstetrics, i.e., the level of the science of obstetrics, nor the skill of the obstetricians can give a clue to the differences. The most prominent difference between the countries was that the provision of midwives and doctors to assist at home confinements was better in Denmark. The tentative conclusion of this paper is that the later but more rapid and radical social and economic changes in Sweden created a stronger need among pregnant women for new social patterns and rituals for the deliveries. The hospitals provided these rituals in a form which was in accordance with the new ideals held by politicians, popular movements, and probably by large segments of the population in general: modernity, hygiene, science, and technology. Women and politicians in Sweden wanted to extend the possibility of hospital deliveries, but for different reasons. Both groups, however, were influenced by the rapid change in Swedish society, and new ideas emerged from each, probably as a consequence of the modernization of society. The faster and more radical changes in Sweden could explain why the change occurred earlier than in Denmark. Among these ideas were new ways to establish causal relations where science and technology came to play a major role in the explanations of changes and improvements. The idea that hospitals reduced perinatal morbidity and mortality appeared earlier in Sweden than in Denmark. Finally, the stronger tradition of state intervention in Sweden may have made more acceptable the political means used to improve the population's size and quality.

\footnotetext{
82 Adolph Jensen, Befolkningsspørgsmaalet $i$ Danmark, Copenhagen, Studentersamfundets Oplysningsforening, 1937; Betankning II, op. cit., note 8 above; Hanne Caspersen, Moderskabspolitik $i$ 1930'erne. Det modsatningsfyldte moderskab, Copenhagen, Danske historiske forening, 1985.
}

\author{
${ }^{83}$ Koch, op. cit., note 63 above. \\ 84 Vallgårda, op. cit., note 32 above, p. 129. \\ 85 Act on health visitors for newborn children from \\ 1937.
}

